\title{
Parental support in sports development of Brazilian gymnasts participants in the Olympic Games (1980-2004)
}

CDD. 20.ed. 796.011

796.48

http://dx.doi.org/10.1590/1807-55092016000100109
Laurita Marconi SCHIAVON* Daniela Bento SOARES*
*Faculdade de Educação Física, Universidade Estadual de Campinas, Campinas, SP, Brasil.

\begin{abstract}
Sports development involves important aspects that collaborate towards the achievement of a high level sports performance. Parental support is one such fact to be considered in Long Term Athlete Development (LTAD), capable of benefiting or harming athletes if not adequately administered. This study registers and discusses the importance of parental support in female Artistic Gymnastics, from the perspective of Brazilian gymnasts who have participated in the Olympic Games. The method used was Oral History with the technique known as oral testimony. The participants of the study were the ten Brazilian gymnasts who represented Brazil in the Olympic Games from when the country first participated in this championship, in 1980, up to the best Brazilian classification in Athens (2004), totaling ten gymnasts (a sample comprising 100\% or the research universe). Testimony analysis was conducted through crossanalysis. The study shows unanimity among the gymnasts in regards to the importance of parental support in the sports development process. In addition to reinforcing the results found in the literature, the testimonies provide details of the relationships between the gymnasts and their families for deeper reflections around the subject, a distinguishing feature of studies with oral testimonies.
\end{abstract}

KeY WoRDS: Gymnastics; Sports; Physical training; Family.

\section{Introduction}

The sports development is influenced by a variety of factors, including, but not limited to, talent, infrastructure, cultural traditions, government support, qualifications of the trainers, coach education, physical training system, the support of a multidisciplinary team and family support. It is possible to affirm that, within the childhood and youth sports context, coaches, parents, siblings, peers and even team managers form a multifaceted and complex social network that wields positive and negative influence over the experience of young athletes ${ }^{1}$.

Different authors agree over the importance of parental support in the development of athletes, even when the achievement of high level sports performance is concerned ${ }^{1-7}$. According to KANTERS and CAPER $^{4}$, the scientific literature increasingly offers evidence that not only do parents' socialization activities in their children's athletic life have an impact in the athlete's initial level, but they also dictate beforehand the choices of permanence in sports in the future. JowetT and Timson-KaTCHIS ${ }^{1}$ highlight that the time and effort young athletes are capable of dedicating to training and competition are dependent on the material and emotional support offered by parents and coaches.

More specifically within Artistic Gymnastics, the influence of the family is widely discussed and emphasized since it is a sport developed since early childhood, something that also happens with other sports such as Swimming, Tennis and Figure Skating ${ }^{8-9}$.

According to Nunomura and Oliveira 7 , "[...] children depend on the parents to transport them to practices, to encourage a correct diet, to give emotional support, to cover costs of training, among other factors" (p.6).

In addition, the parents' opinion regarding trainers or even the methods used in the process of athletic improvement may increase or decrease the distance between coach and athlete, which can be conducive to respectful and trustworthy 
relationships or encourage discontinuity in training, due to strategies such as negative feedback, the search for a new trainer or changing of teams ${ }^{1}$.

In respect to a possible negative influence, studies show that parents often do not notice when their interference is interpreted by the child in ways that foster behaviors expressing pressure and anxiety ${ }^{4}$. In the short term, children tend to maintain their participation in sports in a manner by which they express the answers they perceive as expected by their parents; in the long term, however, children are susceptible to abandoning the sport in an early age. In their study about tennis athletes in youth categories, Gould et al. ${ }^{3}$ stress that $36 \%$ of parents interfere or inhibit the athletic development of their children, through an emphasis on winning, unrealistic expectations, criticism and complaining'.

Lauer et al..$^{5}$, supported by Fredricks and ECCLEs $^{10}$, theorize that parents' involvement in sports can be divided into three roles: provider, interpreter and role model.

As sport providers, parents that make physical activity opportunities available to their children offer youth the chance to sample and experience sport (Côté, 1999). [...] (Parents) also provided the financial support needed to sustain the longterm effort to develop talent (Bloom, 1985). The

\section{Method}

For the development of this qualitative research, the Oral History method was used ${ }^{11-13}$, based on the possibility of obtaining information from people who participated in these important periods of WAG in Brazil, looking to the sports career of these gymnasts $^{14}$. According to QueIroz ${ }^{14}$ :

Oral History is an ample term that covers an amount of accounts around facts not registered by other types of documentation or which one seeks to complete. Collected through various forms of interviews, it registers the experiences of a single or several individuals from a single collectivity. In this case, a convergence of accounts around a single event or a period is sought (p.19). (Translated by the authors).

This method was chosen mainly due to the lack of available records around the sports development of these gymnasts in documents. In addition, it allows for the collection of detailed information regarding the events experienced in the sports career of each second parental role of interpreter influences children's perceptions of competence and the value they place on sports involvement (Fredricks $\&$ Eccles, 2004). Parental beliefs and expectations have been related to young athletes experiencing stress, anxiety, and burnout (Brustad, 1996). [...] Regarding the third role of the parent, as a role model, parents may influence a child's sport behavior by modeling reactions to situations (Fish \& Magee, 2003), demonstrating how to perform sport skills and commit to vigorous training, and even in how they interact with those involved in sport (i.e., coaches, officials, other parents and athletes) (p.487-8).

Thus, parental influence in the sports development of athletes can be quite diverse, acquiring different characteristics in accordance with observed behavior. Additionally, research shows support to be the most important aspect offered by parents, defined as multiple paths that include points referencing financing and training logistics, as well as social-emotional and unconditional support ${ }^{3}$.

In this article, the "parental support" will be discussed through the perspective of gymnasts, by an Oral History perspective, with all Brazilian gymnasts who compete in Women's Artistic Gymnastics (WAG) at the summer Olympic Games (1980-2004).

of the gymnasts that might otherwise have gone unnoticed.

LAVILLE and DionNE ${ }^{15}$ corroborate this claim: A known and proven manner, specific to the human sciences, of obtaining information consists of collecting testimony from people who have this information. Recourse to these testimonies allows for the exploration of people's knowledge, but also of their representations, beliefs, values, opinions, feelings, hopes, projects, etc. (p.183). (Translated by the authors).

Among the various techniques for the development of the Oral History method, "oral testimony" was used in this research. In oral testimony, the researcher proposes a theme around which to organize the life account of those to be studied ${ }^{14}$. The research, in a wider sense, is focused on a particular theme, the "history of sports life" of these gymnasts ${ }^{16}$, and, more specifically in this article, the theme developed, based on the testimonies, as "parental support in sports development". 


\section{Participants}

This research counted with the participation of ten gymnasts, introduced below in chronological order starting with the first participation in the Olympic Games: Cláudia Magalhães (1980), Tatiana Figueiredo (1984), Luisa Parente (1988 and 1992), Soraya Carvalho (1996), Daniele Hypólito (2000, 2004 and 2008), Camila Comin (2000 and 2004), Ana Paula Rodrigues (2004), Caroline Molinari (2004), Daiane dos Santos (2004 and 2008) and Laís Souza (2004 and 2008)a ${ }^{\mathrm{a}}$. The criterion established to determine the subjects was: Brazilian gymnasts participating (or classified) in the summer Olympic Games in WAG up to 2004 (the best Brazilian classification by team in the Olympic Games).

\section{Procedure}

The study utilized unstructured interviews, $[\ldots]$ in which the interviewer supports him or herself on one or several themes and, perhaps, on a few initial questions, thought of in advance, to subsequently improvise the other questions in accordance with his or her intentions and the responses obtained from the interlocutor ${ }^{15}$ (p.190). (Translated by the authors).

The first moment in the interview is conducted in a rather free form, starting with an ample theme $\mathrm{e}^{16}$, which, in this study, was the sports history of each gymnast ${ }^{16}$. In a second moment, the researcher brings up generating themes, directing the conversation towards relevant issues of the participant's sports history, with the intention of delving deeper into certain subjects. A previously elaborated script focusing on prominent moments of the gymnasts' sports history is utilized in this moment of the interview, and, in the case of this article, the generating theme was "parental support in sports development".

This research was previously approved by the Research Ethical Committee of University of Campinas/Faculty of Medicine.

\section{Cross-analysis of data}

The transcribed testimonies were classified into units of analysis, that is, "sets that group according to significance, complying with their being bearers of meaning in relation to the analyzed material and to the intentions of the research"15 (p.216). (Translated by the authors). The accounts given by the athletes around the same theme were grouped into each unit of analysis.

Among the forms that oral history can be constructed, the technique used in this study was cross-analysis. In cross-analysis, "oral evidence is treated as a source of information around which an expository text is organized"13 (p.304). (Translated by the authors). Whenever the prime objective becomes analysis and not the presentation of stories of full lives, "the global form can no longer be directed by the life history as a form of evidence, but should emerge from the internal logic of the exposition"13 (p.304). (Translated by the authors). In general, comparing the evidence from one interview with that of another and associated with evidence from other sources, whenever possible ${ }^{13}$.

The analysis of the results was conducted from the data collected in the field research, in the testimony of the collaborators by themes, in which the units of analysis were represented by the generating theme. Afterwards, each gymnast's data were crossed to allow the relations between them to be established and, from this point, confronted, highlighting and reflecting on the differences and, mainly, the similarities in relation to the parental's support in the sports development of the gymnasts who participated in this research ${ }^{13,17}$.

Following that, a comparative analysis and a discussion around the data from the testimonies were undertaken, using the basis of information gathered in the literature studied, disagreeing, confirming or even offering collaborations with new approaches. This is the main contribution of Oral History, to bring information that is not to be found in official records or even to disagree with existing records, as new evidence, which might indicate paths for a new interpretation ${ }^{13}$.

For the comparison of the participants of this study, they were grouped by similarities in their stories as a whole, an inherent characteristic of oral history as a form of evaluating the coherence of testimonies ${ }^{13}$. Thus, three distinct groups emerged (TABLE 1) and the analysis was subsequently conducted following this same grouping. 
TABLE 1 - Groups of gymnasts comprised by the study sorted by similarities on each period.

Group
Pioneer Gymnasts: gymnasts representing Brazil in Olympic Games mainly in the 1980s. These
gymnasts, in regard to the posterior generations, experienced less support given to the training
system when it comes to financial conditions, material and human resources. There was lack of
support in these aspects in both, the clubs as well as the Brazilian National team. These gymnasts
aimed at a good participation in the Olympic Games, nevertheless without real chances of
medals or not even Olympic finals.

Transition Gymnasts: this group without support and infrastructure, similar to what was experienced by the Pioneer group, nevertheless, at a given moment they had the opportunity to live a better phase in terms of infrastructure. The gymnasts got the first Brazilian good results in international competitions.

New Generation Gymnasts: composed of gymnasts who joined the Brazilian squad when it was already structured with better conditions for an adequate sports preparation, in the similar standard of high level national teams worldwide who compete for medals in the World

\section{Results and discussion}

Family support comprises part of the prominent Brazilian gymnasts' sports careers, mentioned with great importance in their testimonies by all the participants of this research.

According to Simóes et al. ${ }^{18}$ :

Incentive is an essential adult activity for children/ adolescents to acquire self-esteem, control and consciousness of having a parent as an encouraging agent. It is an indication that the adult world performs an effective activity over the sporting lives of children ${ }^{18}$ (p.39). (Translated by the authors).

In regards to the importance of this parental support, Lopes and NunOMURA ${ }^{19}$ assert that the family is one of the main extrinsic motivational factors in the sporting life of a gymnast, which was truly possible to note in the families of all the gymnasts of this study. The testimonies will be replicated below so that the importance that gymnasts give to their relatives may be observed:

My family also supported me, my mother and my father always gave me strength, I was always loved and praised very much. Everything I did, I was the most beautiful girl in the world, I was the cutest, you know, everything very positive. They weren't parents who would meddle, they weren't parents who would meddle and want me to win, who would keep demanding. Whatever happened, I was the most beautiful girl in the world, so I believed them. They said I was, so I was! I wasn't scared, not even insecure, I was very confident and, since I was very competitive, I had a desire to be the best, I wanted to be better in everything, I wanted to win, I wanted the gold medal, I wanted to do more (Gymnast 1).

My family always supported me. My father was always involved, head of the delegation, he participated in the CBG during Fisher's time, he was vice-president of the CBG. He was always club director, always tried to participate. My mother always gave her support, would take me to trainings, would pick me up, everything. Actually, I had a lot of support from them. It couldn't have been any other way. It depends a lot on the family, because it starts early. So, if the parents don't take the kids to the training, don't pick them up, there's no way how. My family went to see me at the Olympics, my parents and my brother (laughs). I liked it when they went. Then we stayed there and went sight seeing. It was great! (Gymnast 2).

So, what stands out strongly in my memory is that I had to practice a physical activity, because that was already part of the family. And not only because my grandfather went to the Olympics in Berlin' $^{c}$, in 36. But, it was an important matter in my family. My father always took swimming classes, played soccer, my siblings always practiced artistic gymnastics, then rowing, then triathlon. My mother played volleyball in 
school, so this influence to practice sports or a physical activity was always very strong in my family. And artistic gymnastics was a sport that, at the time, didn't have much media exposure. [...] But they always supported me. Sometimes I remember how my father and my mother would perhaps have a conflict: "But might she really not be too young for this?", "No, but she likes it so if she likes it and doesn't complain, then let's leave it and let's trust the coach and let's trust that what they're saying is true, that she is talented, that she can go on and has the capacity for this". So, at a certain moment they also hesitated, without flaunting and always encouraging. Because they saw that I was happy that way (Gymnast 3).

Gymnast 4 always had a lot of support from her family, so much that she trained in her father's gym for a few initial years, with equipment that he built, and was himself her coach for many years. Through the testimony, one can notice a very close relationship, even a certain prompting, an "obligation" to be a gymnast, even if unconscious on the part of her family, possibly for wanting too much to help her.

I wanted to stop many times. But my father always had some words: "oh... if you want to stop, I'll support you all the way. But we'll just keep studying, you can look for another sport, but it is your dream to go to the Olympics and when you become a teacher you'll talk about how you went to the Olympics", so I ended up staying. And there was an emotional part. My two sisters stopped. My father loved sports. And I could see him, very excited, very determined, striven to construct material. There were times that we didn't have a fixed place to train. We would go to a club, then, all of a sudden the club: "ah... I don't want you guys here anymore. Go somewhere else”. And these clubs, we would train in the event space. So we would have to assemble and disassemble, reassemble and disassemble the equipment. And I would see my father with the thick gymnastics mat on top of his car going somewhere else, the equipment inside the car. That's how it was, a lot of work. And when both of my sisters stopped, I didn't want to continue either. Because my father was very demanding, there was no ludic moment. Training with him was hard. And I was also not really wanting to train anymore. It had become boring. But even so I stayed: "gosh, but my father works so hard, he'll be so sad". I didn't want to disappoint. So I ended up continuing because I didn't want my father to get upset. I ended up having to bear the brunt of this. [...] The training for the Olympics, to classify in the world championship, never had a starting point. In my mind it had always been my dream. My dad had had it. Deep down I always knew I would go to the Olympics. I had that with me and it was a very natural thing.

I had it in my mind that the Olympics was something that was part of the process. It was something in which I was going to participate. And it wasn't a strategy to be like this, it was very natural. I think that nowadays a lot of people ask: "ah... what are you going to do with your life?” I think I always knew. I think my father would say so often when I was a kid: "ah..., when you grow up you're going to be a teacher, you're going to give classes". I didn't even think about it when I applied for college, and that was what I did. That's how it went.

A strong parents support was reported by Gymnast 6, influencing her motivation to become a gymnast and continuity in the sport quite a bit, even through difficult situations lived by the family, who did not want her to waste the opportunity: My father always had a lot of [financial] difficulty when he was young and today, the situation we live in is more comfortable, but my father struggled a lot to get here, so they've always been telling me, that nothing is free, that you have to dedicate yourself a lot, that you have to train, train and train 10 years to have something, a result and you might not even have it. So my parents, my family had a lot of influence in my sports career.

My family always supported me a lot, without my family I wouldn't have been a gymnast, because, in whatever sport in the beginning, at any difficulty the child wants to stop, wants to quit, always. Any sport. He or she might have talent to spare, but if the parent isn't saying: you're going. The child says that he is feeling lazy, that she doesn't feel well, but the parent says: you're going. I would go to the gym sick, my father would make me go, would make me in a way because he wanted my best. He would say: "I would like to be your coach to be inside the gym", because he knew my temper, he knew I was a worm, so that if I was here when you turned around I wouldn't be here anymore, I would already be doing something else. I was very smart from an early age, I had always been very energetic, very naughty, so if it hadn't been for my 
father specifically, I wouldn't have been a gymnast, wouldn't have become an athlete, nothing. And my mother was the more let's say affectionate part, I give you strength, I help you, my father more severe and my mother on this side, like I would come home and say: "mom I'm tired", then my father would say: "no, you're going”. My mother would say: "look, it's for your own good", would comfort me. And my sister always helped me at school, with assignments that I had to do. [...] My family always supported me, I never had any family problems, of not having my family with me.

Transition generation gymnasts (6 and 7) also speak about the parental support, but with less "obligation" to be an athlete:

I think my family has always been a very important family and continue to be so because my family, they're by my side. Good moments and bad ones. And I know that if I'm having a good moment, they will be there because they'll be happy with my victory, and if I'm not in a good moment, they'll be by my side to help me to improve. So, I think my family is very important and I am privileged. I'm a privileged person for always being able to travel with my brother and I always say, "my brother is not only my brother", it's not like that, "he's only a brother and let's leave it at that", my brother is my friend and my companion and I know that I can count on him for everything. And my older brother too. Us three were always like this (Gymnast 5).

About my family, they always supported me. Always. When I speak to the parents of other athletes, first of all, the child has to want it. Because sometimes the parent wants it more than the child. So I think the child has to want it always more than the parents. I remember in my house it was always like this. My father, of course he liked that I practiced gymnastics. But school came first. gymnastics came second. I always liked it a lot. And they supported me. And I think that this is the parents' role. To support their child in what he or she wants to do. My parents ask: "Do you want to train?". When we went through the surgery thing. I was in pain. Arrived from Athens: "Do you really want to go on?”. I do! "Because as far as we are concerned, if you don't want to anymore it's okay", my parents said. You have to do gymnastics for you! Always. Parents have to give you a base, to help you. "Ah it's great that you're training". So much so that my parents hardly come to
Curitiba. I don't even like it very much that they come. Because I think that sometimes it gets in the way. When you miss them, it's something if they're far away, when they come near, you feel something else when they leave. So the family has to help the person. Be by their side, when needed. Really support. But to want, you're the one who has to want. Always (Gymnast 7).

Within the New Generation of gymnasts, the issue of family support and gymnast life is also unanimous Since the beginning my parents always supported me, they would go to competitions and it was hard to pay for. When I started, we had to pay R\$ 150.00 to train. We didn't have the capacity to pay this amount, it was always a sacrifice, every month, to pay, it was very hard, but in the end it was worth it (Gymnast 8).

So a person, an idol like that I don't have one, but my parents since they always helped me were important in my career. And they gave me strength to get there. My parents, my family really. [...] I always had a lot of support from my family! There was never anyone against. [...] They always helped. When I was in pain they treated me here at home, they would also help me with everything. When I left, they didn't want me to leave. It was complicated at first, but later they came to understand me (Gymnast 10).

About my relationship with my family, it's always been good. They always supported me, never complained. When I went to live on my own at age 11, my mom let me. Because there were some people she trusted. She was sure that nothing would happen with us and it was right there in São Paulo. Real close to Ribeirão. If anything happened she would get a car and be there on the same day. I have a younger sister. I have an older brother. My sister trained for about three years more or less, it was quite a bit, but she didn't like it very much. But they give me a lot of strength. Wow! A lot, a lot (Gymnast 9). According to Simóes et al. ${ }^{18}$ :

The incentive provided by relatives is fundamental: it is very complex in itself; it depends on various factors directly related to each other in a constructive manner in terms of the needs of the relatives and the children/adolescents. There is no doubt that one of the essential roles of the father and of the mother is to encourage children to participate in sports and, therefore, provide 
them with the closest cooperation, and in such a manner accelerate their sports readiness, their maturity and a great variety of activity in the world of fields, courts, pools and tracks (p.38). (Translated by the authors).

When children are involving in sports, it is necessary a close relationship with the family, guiding them around events, emotions, demands, diets, among other aspects, since parents, in general, are not experts and may show difficulty dealing with the situations experienced by an athlete. Guidance for parents is important so that they are conscious regarding how they can aid or harm their children in sports. They might often have good intentions, but the consequences of particular attitudes or excessive demands may leave a mark on a person's life, or even push her to quit the sport due to the influence of these factors.

In some situations, parents' demands for results is seen as a negative form of incentive for children, as mentioned by "Gymnast 5" regarding unhealthy attitudes in relation to demands:

I think something important that I think is important for every athlete, is to have family by his or her side. Not family that is demanding. Because I believe that family is the foundation of the athlete. Now, if the family starts to demand of a five-year-old child that she has to be a winner, the child might, perhaps, not reach the stage of competition. Because in this phase it is when the child has to say, "dad, I did it!", and the parent: "wow son, congratulations!", has to be the first one to applaud, not the first to say: "today you didn't do a good cartwheel". So, I think that, really, what is necessary to point out is that the family should always be by the athlete's side, and not be demanding, being the first to demand more from the athlete.

RYAN" ${ }^{8}$, in the book "Little girls in pretty boxes", highlight the exaggeration of some parents in relation to the dedication to their daughters (gymnast and figure skater), and stresses how a few come to "live the life" of their daughters. The same author describes the exaggeration of some parents regarding the possibility of their children making it into the National United State Team and earning well: "With so many of the parents treating their children like commodities, it begins to seem normal; and no matter how harsh a parent might be, he or she can always rationalize by finding a parent who's worse.” (p.149).

LAUER et al. ${ }^{5}$ portrays how specific behavior and attitudes by parents may help or inhibit the development of sports talent. This information could be passed on to parents with the objective of facilitating talent development and helping young athletes to have positive sports experiences. Assertions relevant for development would be those that include display of affection and support; negative actions would be related to criticism, yelling and lack of incentive from the family.

In agreement with, JowetT and TimsonKATCHIS $^{1}$ affirm that it is necessary that there be a balance between the degree and nature of the influences that the parents exert over their children and trainers, for excessive support on their part may provoke negative feelings, among which are pre-competition anxiety and friction with sports, and a distancing within the trainer-athlete dyad.

On the other hand, when well-guided, the parental's support may collaborate in this process, for the lines of communication between parents and children may create opportunities for the children to communicate their feelings about the process ${ }^{4}$. These paths may be encouraged by coaches and, certainly, may help in the athlete's development process.

The Andreea RADUCAN ${ }^{20, d}$ biography, provides an account of the importance her father had from the start of sports practice and of his influence in the emotional aspect:

I was only five years old when one day after a training session I told him (her father) that I didn't want to go up on the beam. I was afraid that the beam was too high and too thin. "Go up and have no fear. Daddy is right here waiting for you on the other end of the beam", he would say. I remembered his reply countless times in my life. Each time I struggled, daddy was waiting for me "on the other end of the beam" to make things better for me. Maybe it wasn't an accident that the beam became my favorite apparatus as high and thin as it was (p.8).

Parents' behavior around their children's inquiries and observations may have a relevant influence and should be considered by all those involved in this process, as well as guided.

According to SimóEs et al. ${ }^{18}$, "[...] the manner in which fathers and mothers act towards their children seems to be significant for the establishment of a set of well-defined lines of participation in the sports life of children" (p.41). (Translated by the authors).

In regards to this proximity and parents' guidance, Gymnast 6 comments that, starting at a particular moment, her parents were called to discuss the seriousness of the work, the real possibilities for 
their daughters and the course of action to be taken at home to help in the trainings:

When I moved to the Center of Excellence that had the selection, everything changed. There was weight control and up until then there hadn't been, there was work to do during vacation, so things started to get more serious, there was more parent involvement as well. They already knew that we couldn't be gymnasts only in the gym, we had to be gymnasts outside, at home. So I couldn't go out at night anymore, I couldn't have dinner out anymore because I had to train the following day, I had to rest, I couldn't go to an event late, so from that moment my life started to change. At 13 years old I started to not be a normal person, so I couldn't miss out on training, I would have to go sick, if I didn't I would have to call and justify the absence, the involvement grew. The demands did as well!

Gymnast 8, who always trained in the same places as Gymnast 7, with similar guidance, also speaks about her family's behavior in helping her:

With my family and sporting life: everything connected, interconnected, fights at the gym, fights at home, fights at home, fights at the gym, there was no separating them. They had to change their routine because of me. My mother wouldn't buy cream-filled cookies because I couldn't eat them, my brother would say: "mom, I'd really like to eat some pizza...", but my mother would say: "let's wait for her to travel". But I didn't understand that, I would get angry, I wanted some too, but it was for my own good. Now I see that, but back then I couldn't.

The testimonies demonstrate that all of the collaborators of this study had significant support from their families to become gymnasts, by offering an adequate family structure so they could concentrate on trainings, without further family problems. The family was, at many times, a determinant factor in the process, especially in regards to motivation to continue with daily trainings, or even stimulation in precise moments, important ones in the life of a child/athlete, as accounted by Gymnast 2:

I remember I loved it, I think it wasn't anything too severe. I don't have many remarkable memories, to be honest. I remember the first competition, I remember I didn't even do very well (laughs), I didn't even understand why the other girls received medals (laughs), I didn't get any medals (laughs) and cried a lot (laughs). But my mother always, of course, stimulated me. One has to have parental support, or else...
Based on this relationship of stimulus and support from the family, eight out of the ten gymnasts mention their parents as the people who know the most about their sports careers, always demonstrating complicity and support, as Gymnast 8 cites: "My mother would tell my story the exact same way as me. She knows everything".

Gymnast 2 also mentions her family's participation in her sports life: "I think my parents know my entire story (laughs). And my father, since he was involved in gymnastics, also travelled. He went to the World Championship, to the Pan as head of the delegation, he was always with me".

Gymnast 9 talks about this complicity with her mother, even with her daughter living far away:

If someone had to tell my story, it would be my mother. Most things, going through some difficult moment and she was always by my side. She knows, ever since I went to the first competition she had to struggle to get money to buy a coat, to pay for the plane ticket, even today. Competitions nowadays, she can tell, sort of, how they went, and not really the trainings, because she could never accompany me. But she can tell you well about trips and my humor outside of the gym.

The results of this study corroborate, therefore, the ones mentioned by LaUer et al. ${ }^{5}$, by indicating that the development of sports talents depend not only on the efforts of the athletes, but also on a support system in which, many times, parents are the great supporters, investing efforts and resources of a diverse nature in sports objectives.

With unanimity in the testimonies in relation to the importance of parental support, this research confirms the existing data in other sports around the same theme; and the recording of how support was developed with this group of high performance gymnasts stands apart, due to the difficulty in accessing this type of data from international-level athletes and because of the particularities of this sport, of it generally being started at an early age.

Moreover, it is important to emphasize that this type of study seeks not only to register and divulge data about the development process of high performance gymnasts, but that it also brings reflections to coaches, families and managers around the conduction of this process.

Based on the premise that the family has no experience in sports, it is the role of the physical education professional, in this case, of coaches and/ or sports institutions, to guide parents of children in sports. With this end, the institutions and coaches 
themselves need to know of the importance of the family's healthy presence in sport, which does not always happen, generating distance between coaches and relatives, who could join forces toward the through development of athletes. The coach-athletefamily triad needs to be considered in long-term athlete development, starting at the sports initiation up through the highest level sports performance.

\section{Notes}

a. The gymnasts authorized the use of their names for scientific purposes, an important fact for studies within Oral History, which normally have the names of their subjects exposed due to their importance. Since the number of subjects in this type of qualitative research is not large, it is important to highlight their relevance in the context of the research.

b. First president of the CBG (Brazilian Gymnastics Federation).

c. In Rowing.

d. Romanian gymnast "All around" champion in the Sydney Olympic Games/2000.

\section{Resumo}

0 apoio da família na formação esportiva de ginastas brasileiras participantes de Jogos Olímpicos (1980-2004)

A formação esportiva envolve aspectos importantes que colaboram para o alto rendimento esportivo. 0 apoio da família é um dos fatores a serem considerados na preparação esportiva de muitos anos, podendo beneficiar ou prejudicar os atletas caso não seja bem conduzido. A presente pesquisa registra e discute a importância do apoio da família na Ginástica Artística feminina, na perspectiva de ginastas brasileiras participantes de Jogos Olímpicos. 0 método utilizado foi a História Oral com a técnica de depoimentos orais. As 10 participantes dessa pesquisa são todas as ginastas brasileiras representantes do Brasil em Jogos Olímpicos desde a primeira participação do país nesse campeonato, em 1980, até a melhor classificação brasileira, em Atenas (2004), totalizando 10 ginastas (amostra de 100\% do universo da pesquisa). A análise dos depoimentos foi feita por meio da técnica de análise cruzada. Como resultado, todas as ginastas foram unanimes em relação à importância do apoio familiar no processo de formação esportiva. Além de reforçar os resultados presentes na literatura, os depoimentos revelam detalhes da relação entre as ginastas e suas famílias para maiores reflexões acerca do tema, um diferencial de estudos com depoimentos orais.

PalaVRas-chave: Ginástica; Esporte; Treinamento esportivo; Família.

\section{References}

1. Jowett S, Timson-Katchis M. Social networks in sport: parental influence on the coach-athlete relationship. Sport Psychol. 2005;19:267-87.

2. Côté J. The influence of the family in the development of talent in sport. Sport Psychol. 1999;13:395-417.

3. Gould D, Lauer L, Rolo C, Jannes C, Pennisi N. Understanding the role parents play in tennis success: a national survey of junior tennis coaches. Br J Sports Med. 2006;40:632-6.

4. Kanters MA, Casper J. Supported or pressured: as examination of agreement among parent's and children on parent's role in youth sports. J Sport Behav. 2008;31:64-80.

5. Lauer L, Gould D, Roman N, Pierce M. Parental behaviors that affect junior tennis player development. Psychol Sport Exerc. 2010;11:487-96.

6. Gustafsson H, Hassmén P, Hassmén N. Are athletes burning out with passion? Eur J Sport Sci. 2011;11:387-95. 
Schiavon LM \& Soares DB.

7. Nunomura M, Oliveira MS. Parental support on young gymnasts career. Sci Gymnastics J. 2013;5:5-17.

8. Ryan J. Pretty girls in little boxes. New York: Doubleday; 1995.

9. Baxter-Jones ADG, Maffulli N. Parental influence on sport participation in elite young athletes. J Sports Med Phys Fitness. 2003;43:250-5.

10. Fredricks JA; Eccles JS. Parental influences on youth involvement in sports. In: Weiss M, org. Developmental sport and exercise psychology: a lifespan perspective. Morgantown: Fitness Information Technology; 2004. p.145-64.

11. Meihy JCSB. Manual de história oral. São Paulo: Loyola; 2005.

12. Simson ORM. Experimentos com histórias de vida: Itália-Brasil. São Paulo: Vértice; 1988.

13. Thompson P. História oral: a voz do passado. Rio de Janeiro: Paz e Terra; 1992.

14. Queiroz MIP. Relatos orais: do “indizível” ao “dizível”. In: Simson ORM, organizador. Experimentos com histórias de vida: Itália-Brasil. São Paulo: Vértice; 1988. p.14-43.

15. Laville C, Dionne J. A construção do saber: manual de metodologia da pesquisa em ciências humanas. Porto Alegre: Artes Médicas Sul; 1999.

16. Schiavon LM. Ginástica artística feminina e história oral: a formaçáo desportiva de atletas brasileiras participantes de Jogos Olímpicos (1980-2004) [tese]. Campinas(SP): Universidade Estadual de Campinas; 2009.

17. Simson ORM. A arte de recriar o passado: a metodologia da história oral e suas contribuições à promoção do envelhecimento bem sucedido. In: Neri A, org. Desenvolvimento e envelhecimento: perspectivas biológicas, psicológicas e sociológicas. Campinas: Papirus; 2006. p.141-60.

18. Simões AC, Böhme MTS, Lucato SA. A participação dos pais na vida esportiva dos filhos. Rev Paul Educ Fís. 1999;13: 34-45.

19. Lopes P, Nunomura M. Motivação para a prática e permanência na ginástica artística de alto nível. Rev Bras Educ Fís. Esp. 2007;21:177-87.

20. Raducan A. The other side of the medal. Bucharest: Wiseman; 2000.

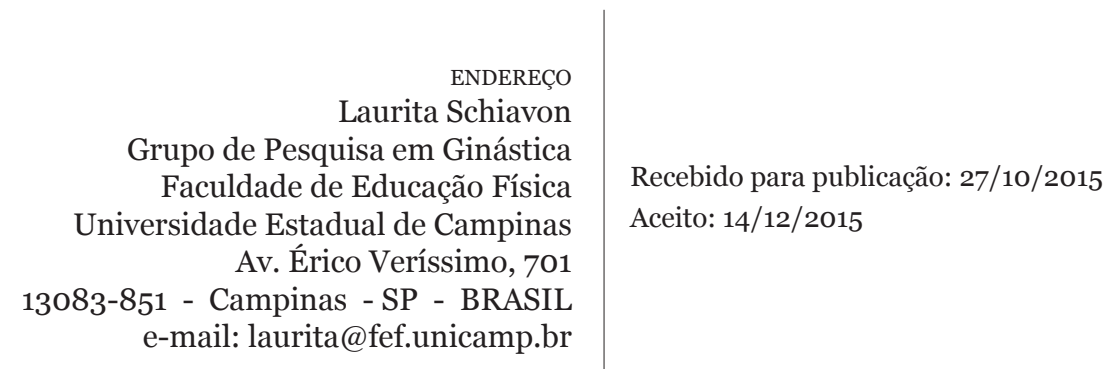

118 • Rev Bras Educ Fís Esporte, (São Paulo) 2016 Jan-Mar; 30(1):109-18 